\title{
17
}

\section{Treaty of Waitangi settlements: Successful symbolic reparation}

\author{
Janine Hayward
}

\section{Treaty settlements as policy success}

New Zealand's ambitious Treaty of Waitangi settlements policy aims to achieve the 'full and final' settlement of the historical injustices Māori suffered through Crown ${ }^{1}$ action and inaction that breached the 1840 treaty. In the broadest sense, treaty settlement policy can be judged a success. The process of addressing treaty grievances began tentatively in the 1970s under considerable, sustained pressure from Māori. It gathered momentum in the 1990s with bipartisan political support (despite public ambivalence) and is now nearing completion. The Waitangi Tribunal is the independent commission tasked with inquiring into Māori claims and making recommendations to the government for redress. To date, it has issued more than 100 reports relating to almost 80 per cent of New Zealand's landmass. The government department negotiating treaty settlements, the Office of Treaty Settlements (OTS), aims to complete historical settlements with all 'willing and able groups' by 2020. By March 2018, the OTS had completed more than 60 settlements.

1 'The Crown' is used when discussing treaty settlement policy to refer to the non-Māori treaty partner. At different times in New Zealand history, 'the Crown' could refer to the Queen, colonial government, representative settler government or contemporary government. 
The Crown's purpose in developing the settlement policy has been, in its own words, to 'devise an approach to financial and commercial redress' through negotiated settlement that resolves Māori grievance, contributes to Māori economic and social development and is fair between different Māori claimant groups. This approach also 'takes account of New Zealand's ability to pay, considering all the other demands on public spending such as health, education, social welfare, transport and defence' (OTS 2002: 87).

The significance of treaty settlements broadly speaking cannot be underestimated. Settlements have altered New Zealand's political, economic and social landscapes. The process has, arguably, laid bare New Zealand's colonial history, established new relationships between the Crown and iwi (tribes) and reestablished an economic and cultural base for future local and regional Māori development. The New Zealand public has not been directly engaged in this policy process; it is kept at arm's length from settlements, which are a political negotiation between the treaty partners, Māori and the Crown. Private land cannot be used in settlements. This has also relieved the public of 'guilt by association'; New Zealanders today are not held accountable for the sins of their colonial past. Public support for settlements policy has waxed and waned over the years; despite this, governments of the left and the right have stayed the course.

Using Marsh and McConnell's (2010) framework for assessing policy success, the following discussion of the treaty settlement policy reveals that, in programmatic terms (which relate to the implementation and outcomes of the policy), the value underpinning the policy from the perspective of Māori was always clear. Māori have argued tirelessly since 1840 for the Crown to honour the treaty. By the 1970s, their protests could no longer be ignored and the government saw value in acting pragmatically to take the heat out of Māori demands. As time went on, governments came to see treaty settlements as 'the right thing to do'. The treaty settlement process has evolved as events and incidents have encouraged-and, in some cases, forced-the government and Māori to act. Crocker (2016: i) describes the policy as responding to 'a combination of factors, such as the broad context of the "Māori Renaissance", social shifts in understanding the past, legal cases and political pressure from iwi'. The success of the settlements policy in terms of outcomes is also clear, to an extent. Māori grievances have been heard and acknowledged for the public record; the Crown has atoned and made some reparations for its historical actions and inactions that caused extensive grievances for Mãori. The policy has 
also been enduring and enjoyed bipartisan support. But, as McConnell (2010: 351) notes: '[S] uccess is in the eye of the beholder, depending on the factors such as a protagonist's values, beliefs and extent to which they are affected by the policy.' From the perspective of Māori, who are most affected by the policy, the policy's success is qualified: only a fraction of Māori loss has been repaired and the material and political outcomes for Māori are limited.

In terms of process (relating to the legitimacy and sustainability of the policy), both Māori and the Crown have done considerable learning over time as the extent of treaty grievances and the scale of the project became clear. Māori have adapted as the Crown's policy process unfoldedat times pushing back against limitations imposed by the government relating to the redress paid to Māori and the time frame for the process. The Crown has also shown, as discussed below, some willingness to adapt and develop the policy over time in response to Māori demands and changing circumstances.

Settlements policy is also significant in political terms, particularly in relation to the way various governments have managed to sustain the policy through time, despite the public's ambivalence (and sometimes hostility) towards it. The policy itself has never been legislated; it is a political conversation sustained over several decades between the treaty partners. This relationship has endured and developed despite a general lack of public support for the policy over time. Both treaty partners have evolved and been shaped by the necessary political manoeuvring, negotiation, tension and compromise. But perhaps the most striking thing about the policy process is its endurance through time-surviving for over 40 years and five changes of government since its earliest inception in 1975.

\section{Contexts, challenges, agents}

Māori had lived in Aotearoa New Zealand for many centuries prior to the arrival of Europeans (Anderson et al. 2014). By 1840, Māori had been engaging productively with traders from around the world for many decades. However, amid increasing Māori concerns that their authority in their own lands was under threat, they signed a treaty in 1840 with the British at Waitangi in the Bay of Islands. Drafted by the British and translated into te reo Māori (the Mãori language), the Treaty of Waitangi 
succinctly describes an exchange of rights and obligations between two sovereign nations. But the two versions of the treaty describe these rights in significantly different ways; the Māori-language version of the treaty was debated and signed by the majority of Māori rangatira (chiefs).

In the first article of the English-language treaty, Māori 'cede to Her Majesty the Queen of England absolutely and without reservation all the rights and powers of Sovereignty'. In the Mãori-language treaty (translated back into English), however, the chiefs 'give absolutely to the Queen of England forever the complete government over their land'. In the second article in English, Her Majesty guarantees to Māori

the full exclusive undisturbed possession of their Lands and Estates Forests Fisheries and other properties ... so long as it is their wish and desire to retain the same in their possession. (Orange 1987: 31)

The Māori translation, however, says:

The Queen of England agrees to protect the chiefs, the subtribes and all the people of New Zealand in the unqualified exercise of their chieftainship over their lands, villages and all their treasures. (Orange 1987: 326)

The third article of the treaty, in both languages, extends to Māori all the 'Rights and Privileges of British Subjects' (Orange 1987).

Despite the treaty's guarantees to Māori for 'unqualified chieftainship over their lands', protected by the Queen's governance, Māori rapidly lost control of their land after 1840 through Crown actions and inactions, including land confiscations, dubious land sales, the individualisation of land title (which Māori had traditionally held communally) and other mechanisms. By the early twentieth century, Māori had lost possession of most of their lands and resources (Ward 1999). The socioeconomic cost of this loss was soon apparent. Māori migrated in large numbers into cities and became overrepresented in statistics relating to poor health, low educational achievement, substandard housing and unemployment. Throughout this time, Māori tirelessly maintained calls on the Crown to honour its treaty obligations (Walker 2004).

In the late 1960s and early 1970s, circumstances converged to finally draw the nation's attention to the guarantees the Crown had made to Māori in the treaty and to confront questions about race relations in New Zealand (Hamer 2004: 3). Māori protests, marches and occupations heaped pressure on the government to address the loss of Māori land and 
to honour the treaty's guarantees. It was one particular protest, however, that captured the nation's attention at a crucial time. A hikoi (march) in 1975 from the top of the North Island to the parliament buildings in Wellington confronted the New Zealand public with images of large numbers of Māori men, women and children marching beneath banners proclaiming, 'Not one more acre!'. Within an international environment charged with American civil rights and South African antiapartheid protests, the whole of New Zealand, and beyond, looked on as New Zealand's own 'race relations' were put under the spotlight. Māori protesters erected a tent assembly in the parliament grounds and refused to leave until the government took action.

Inside parliament, Māori MP Matiu Rata proposed a Bill to establish a commission of inquiry to address Māori demands. Rata was pioneering a uniquely New Zealand response to confronting its colonial past. The government-unaware of the full extent of Māori grievance and anxious to take the heat out of Māori protest and avoid international embarrassment (Hamer 2004: 5-6) — passed the Treaty of Waitangi Bill into law in October 1975.

The Treaty of Waitangi Act established a commission, the Waitangi Tribunal, to inquire into Māori allegations of Crown treaty breaches that occurred after 1975. The legislation was introduced by a Labour government and passed into law by the National Government that came to office in 1975. Despite its bipartisan support, the tribunal's contemporary jurisdiction did not appease Māori demands for long. In 1985, as Māori pressure began to mount again, the government-still unaware of the extent of Māori historical grievance — granted the tribunal a retrospective jurisdiction to inquire into the Crown's actions and inactions dating back to 1840 . This irrevocably changed the landscape of Crown-Māori relations and set the stage for an ambitious and significant policy to address and redress New Zealand's colonial past. The tribunal itself could not negotiate or settle treaty grievances, but it could hold hearings, produce reports and make recommendations to the government in relation to treaty breaches. Over the next 15 years as the tribunal diligently went about this task, successive governments-particularly the National Party Government of the 1990s-would come to appreciate the scale of the project ahead. From 1990 to 1999, the government established an institutional framework and policy process to negotiate, settle and redress the large numbers of historical grievances Māori were bringing to the Waitangi Tribunal. 


\section{Box 17.1 The Waitangi Tribunal}

The Waitangi Tribunal was established in 1975 under the Treaty of Waitangi Act. It is a permanent, independent commission of inquiry with authority to inquire into Māori claims of Crown actions and inactions that breached the principles of the 1840 Treaty of Waitangi. For the most part, the tribunal makes recommendations to the Crown to redress treaty breaches.

The 1980s were a time of dramatic economic, social and cultural change for New Zealand. The Labour Government (1984-90) implemented a radical program of economic and social reform and supported significant social policy developments that advocated for biculturalism in social policy (New Zealand 1988). Changes were also occurring beyond government: Pākehā (non-Māori) historian Claudia Orange published The Treaty of Waitangi (1987), which began to shape a new national narrative about New Zealand's founding document and colonial past. Court rulings also changed the landscape of treaty relations between Māori and the Crown. In 1987, the Court of Appeal had cause for the first time to define the 'principles of the Treaty of Waitangi' (a phrase first used in the Treaty of Waitangi Act). In brief, the Court of Appeal held that the Crown was not acting according to its own legislative requirement (under the StateOwned Enterprises Act 1986) to take into account the principles of the Treaty of Waitangi. It defined those principles as - among other thingsthe Crown's duty to act reasonably and in good faith and to actively protect Māori interests. ${ }^{2}$ The court instructed the Crown to negotiate with Māori to address these concerns, which the Crown proceeded to do.

In 1988, the Waitangi Tribunal was given the power to make binding recommendations on the Crown in very specific circumstances. The tribunal has used this binding authority only once, but it has been described as the 'sword of Damocles' hanging over the government and encouraging progress on claims (Graham 1997: 50-1). In 1989, a second court case, over forest rentals, led to the establishment of a key institution in the treaty settlement process, the Crown Forestry Rental Trust. The trust was paid rents from leased Crown forest lands and this money was used for research to support treaty claims. The funding was significant and, over time, the rental trust became a more substantial contributor to treaty claims research than even the Waitangi Tribunal itself (Wheen and Hayward 2012: 18).

2 New Zealand Maori Council v Attorney-General, 1987, New Zealand Law Reports 1: 642-3. 
Within this charged political environment in the late 1980s, the Waitangi Tribunal began to report on the first of its claims. In response, the Labour Government established the Treaty of Waitangi Policy Unit in 1988 within the Department of Justice to coordinate the Crown's response to the tribunal's recommendations. In 1989, the government announced a set of principles that would apply to all settlements that it hoped to negotiate with Māori on a pantribal basis (Jones 2016: 89). These included the principles of government (by the Crown), self-management (by Māori), equality, reasonable cooperation and redress (Department of Justice 1989). The courts' interventions in treaty issues were not welcomed by the government, and it took the opportunity to assert that treaty settlements would be political—not legal—negotiations including only Māori and the Crown. As Durie notes (1998: 188):

By 1989 when the government published its Treaty of Waitangi principles, it was obvious that the Crown was planning a deliberate strategy to return Treaty issues to the political arena, rather than relying on the [Waitangi] Tribunal or a court of law ... Sir Robin Cooke [Court of Appeal judge] had concluded that it was ultimately for the courts to decide whether the government met its obligations under the principles of the Treaty of Waitangi. [Prime minister Geoffrey] Palmer responded, 'It must be made clear that ... the government will make the final decisions on Treaty issues.'

When the National Government came to office in 1990, it maintained the Labour Government's aspiration to get treaty issues out of the courts and return them to the political arena. For the next 10 years, as discussed below, the National Government-and, in particular, its Minister of Treaty Negotiations, Douglas Graham-developed the treaty settlement institutions and processes that would manage the volume of reports and recommendations emerging from Waitangi Tribunal hearings. Although the Labour Government's support of treaty claims is explained by Māori voters' traditional support for Labour MPs, the National Government's engagement with treaty settlements after 1990 is less immediately selfevident, particularly against a backdrop of public disquiet about the cost to taxpayers of settling treaty grievances. 


\section{Policy design and evolution}

After 1990, the National Government began in earnest to develop the institutions required for treaty settlements. It was treading a fine and difficult line between Māori expectations and poor public understanding of and tolerance for the treaty. In the National Government's first term (1990-93), it was also presented with broader challenges as it continued to pursue the economic and social policy agenda established by the previous Labour Government. Its policies relating to treaty settlements have been described as 'more reactionary than deliberate' and progress on settlements was hard fought and won. But the number of claims registered with the Waitangi Tribunal was increasing: by 1990, 90 claims were registered and, by 1993 , that had increased to 423 (Crocker 2016: 111).

In September 1992, Cabinet agreed on the concept of a fund to pay settlement compensation for historical claims. At the same time, private land was excluded from settlements in response to public outcry that landowners should not feel the impact of the Crown's redress to Māori. 'Land banks' were established to set aside surplus Crown land available for settlements. Also in 1992, the government concluded a complex pan-Māori negotiation relating to fisheries. Through the Treaty of Waitangi (Fisheries Claims) Settlement Act 1992, the government compensated Māori losses of fisheries with $\$ 170$ million worth of fishing quotas and part-ownership of the Sealord fishing company. The settlement became known as the 'Sealord deal'.

Perhaps bolstered by its success in fisheries, the National Government devised its own principles to guide the emerging settlement process without significant consultation with Māori (Crocker 2016: 120). The government was aware that it needed to offer reassurance to the New Zealand public that settlements were justified, in the public interest and would not be detrimental to non-Māori New Zealand. A 1994 opinion poll of 1,000 adults found that over 70 per cent thought Mãori 'get a fair go' in New Zealand and there was no need to embark on settlements (Crocker 2016: 103). The government's principles-paraphrased and as amended by the Labour Government in 2000—are (OTS 2002: 30):

- Good faith: The negotiating process will be conducted in good faith based on mutual trust and cooperation towards a common goal.

- Restoration of relationship: The restoration of Crown-Māori relations is integral and will be reflected in any settlement. 
- Just redress: Redress should relate to the nature and extent of the breaches suffered, with existing settlements benchmarking future settlements where appropriate.

- Fairness between claims: Claimant groups must be treated consistently in terms of the levels of financial and commercial redress to ensure the durability of claims.

- Transparency: Claimants must have sufficient information and the general public must be encouraged to understand the settlement process.

- Government-negotiated: Negotiations are between the government and claimants as the only two parties who can, by agreement, achieve durable, fair and final settlements.

In 1993, the National Government created the portfolio of Minister in Charge of Treaty Negotiations to bring leadership to the negotiations process. The appointment of Douglas Graham as the first treaty settlements minister was crucial to the progress made over the following years. Graham accepted that wrongdoing had occurred on the part of the Crown and was aware of the weight of Māori demands. He brought his often-reluctant colleagues in the National Government with him as the settlement process began to take shape. His investment in treaty settlements, supported by then prime minister James Bolger, was essential to establishing the bipartisanship that has characterised treaty settlement policy since the 1990s. As Māori scholar Mason Durie (1998: 194) notes:

Doug Graham, as Minister in Charge of Treaty Negotiations, carried out much of the burden and in so far as the outcomes have been successful, much of the credit must rest with him.

In 1994, the government released the details for its comprehensive proposals to settle all claims without utilising natural resources or the conservation estate, and to limit the total value of all claims to a billion dollars' within a 10-year time frame (Durie 1998: 191). As Crocker (2016) notes, the idea of a fund for settlements had been discussed among officials since 1992, although the figure of $\$ 1$ billion including the fisheries settlement was a political decision, made by Graham and the Cabinet. There was also debate within the Cabinet about whether that fund should be legislated for; again, under Graham's guidance, the decision was made that the settlement fund would be policy, not law (Crocker 2016: 108-9). The government's policy also distinguished between historical and contemporary treaty claims; grievances relating to matters prior to 
21 September 1992 (the date of the Cabinet committee meeting) would be historical claims subject to the limits of the fund, while those after 1992 would be contemporary claims.

As previously noted, the government's policy was developed with 'negligible Māori input' (Durie 1998: 190) and was soundly rejected by Māori, who objected to both the lack of consultation and to the low level of compensation available for historical settlements (Palmer 2008: 264). In January 1995, Māori across the country gathered together and unanimously rejected the proposals. Of all the aspects of this policy, the billion-dollar limit on redress—dubbed 'the fiscal envelope'—was the most controversial. Durie notes:

The amount was non-negotiable ... [and] neither the methodology used to calculate the amount, nor the basis for deciding affordability was disclosed. The cap was simply stated as a given, even though most claims had not yet received due consideration, while others had yet to be filed.

(1998: 192)

By April 1995, the future of the fiscal envelope was in doubt, although it appeared in the government's budget in 1995 and again in 1996. Despite these setbacks, the government pushed ahead with the institutional structures required to negotiate settlements with Māori. In 1995, the OTS replaced the Treaty of Waitangi Policy Unit with a mandate to negotiate and settle Māori claims on behalf of the government. Also in 1995, the Crown achieved its first historical settlement, with WaikatoTainui Māori. The passage of the Waikato Raupatu Settlement Act 1995, which gave effect to the settlement, was historic: for the first time, the Queen gave her royal assent to New Zealand legislation in person during a royal visit to the country (Durie 1998: 195).

\section{Box 17.2 The Office of Treaty Settlements}

The Office of Treaty Settlements is a government department within the Ministry of Justice. It was established in 1995 to negotiate the settlement of historical Treaty of Waitangi claims.

Following the general election in 1996, the government was forced to formally abandon the fiscal envelope as a result of coalition negotiations between National and the minor political party New Zealand First. By that time, however, three settlements had been negotiated using the fiscal restraint set out in the policy: the fisheries settlement, Waikato-Tainui 
and the Ngāi Tahu settlement, which covered most of the South Island of New Zealand (Durie 1998: 193). The Waikato-Tainui and Ngāi Tahu settlements included 'relativity clauses' in their legislation to safeguard those claimants against future increases in the overall quantum. At about $\$ 170$ million each, those settlements constituted about 17 per cent of the overall quantum the government had set aside for settlements. If more was spent than the anticipated $\$ 1$ billion in settlements, those iwi would receive additional redress to maintain their relative share of the overall amount.

In 1997, the Waitangi Tribunal published its 'National Overview' reports to encourage the government to appreciate that settlements would ultimately cover most of New Zealand's landmass and involve all iwi. The tribunal also began to develop new ways of hearing claims and reporting more quickly to government in response to the growing number of claims. For example, it made improvements in the way it organised the vast amounts of evidence it managed for major historical inquiries and the way it conducted its hearings, thereby reducing the number of years typically required for large-district inquiries (Waitangi Tribunal 1997).

Despite the tribunal's innovations, government concern was mounting about how long it was taking for large claims to proceed through the inquiry process. When Labour came to power in 1999, it encouraged Māori claimants to consider direct negotiations with the Crown, rather than pursuing their claims through the Waitangi Tribunal hearings process. As Māori scholar Carwyn Jones (2016: 89) notes, from that time, the Waitangi Tribunal, 'while still important to Māori, became slightly peripheral to the settlement process'. In 2002, the tribunal registered its 1,000 th claim and the pace of new claims showed no sign of abating. Amid mounting public pressure for the government to signal an end to the treaty settlement process, the Labour Government passed a significant and controversial amendment to the Treaty of Waitangi Act (Section 6AA), in 2006, to once again limit the tribunal's jurisdiction. After 1 September 2008, no Māori would be able to submit a historical claim to the tribunal (defined as acts or omissions by the Crown before 21 September 1992). An unprecedented 1,800 historical claims were lodged with the tribunal in the few years prior to the 2008 deadline; this was more than the number of claims the tribunal had previously received in its history. This influx of claims brought new challenges for the tribunal to develop processes to determine which of those claims would be accepted and how to reach finality with all historical claims. Many Māori could see some merit in 
proposals to advance claims. As Durie (1998: 193) notes: 'The idea of putting to rest long-standing grievances as soon as possible made sense; and the advantages of avoiding costly litigation had considerable appeal.' Overall, however, from 2000 to 2006, the Labour Government found it hard to make settlements with Māori despite their historical relationship through the Māori electorates (which Labour MPs had traditionally won). Instead, this period was characterised by a rift that opened between Māori and Labour after the government legislated to remove legal avenues for Māori to pursue treaty claims to the foreshore and seabed (Boast 2005).

When National came back into office in 2008, it increased the pace of treaty settlements and further developed the infrastructure around the policy. The appointment of Christopher Finlayson as the Minister in Charge of Treaty Negotiations created a momentum in settlements last seen when Graham held the position in the 1990s (Dreaver 2017: 116-17). Finlayson spearheaded further innovations in treaty negotiations, establishing a more senior Crown negotiating team and placing a greater emphasis on comprehensive settlements encompassing a single region at the same time (Dreaver 2017: 116-17). In 2013, National also established the Post Settlement Commitments Unit, which had responsibility for auditing Crown compliance with settlement agreements. New positions relating to treaty settlements were also established in key government departments not traditionally aligned with treaty settlements, such as the Ministry for Business, Innovation and Employment. These roles were looking to the future and 'tasked with responding to the enhanced expectations and capacity of iwi and hapū [subtribes] following settlement' (Dreaver 2017: 120).

In 2015, the Waitangi Tribunal announced its ambition to complete historical (pre-1992) claims by 2020 and to then transition into the completion of all other outstanding claims by 2025. The National Government maintained its own policy (albeit with a shifting deadline) to settle all historical grievances. By October 2017, when Labour again took office, 85 deeds of settlement had been signed by the Crown, reflecting approximately 61 per cent of the expected settlements. As the OTS (2017) noted in its brief to the incoming government, approximately 53 claims remained unsettled, although the Crown was actively engaged in negotiations with 47 of these groups, some of which were close to settlement. 


\section{Delivery, legitimacy and endurance}

The negotiation and settlement of Treaty claims have generally followed a four-step process, established by the National Government in the 1990s and modified by the Labour-led Government after 2000: 1) preparing for negotiations, 2) pre-negotiations, 3) negotiations, and 4) ratification and implementation. It is important to reiterate that these processes are not governed by law, but rather are political negotiations between Māori and the Crown.

In preparing for negotiations, Māori register a claim with the Waitangi Tribunal. Under Section 6 of the Treaty of Waitangi Act 1975, the tribunal has the authority to consider claims by any individual or group of Māori claiming they are, or are likely to be, prejudicially affected by (among other things) ordinances, regulations, policies, actions and inaction by or on behalf of the Crown. For the purposes of the Act, 'Māori' is defined as 'a person of the Māori race of New Zealand; and includes all descendants of such a person'.

Once a claim is accepted and registered, claimants proceed to negotiations through Waitangi Tribunal hearings and report writing or they seek direct negotiations with the Crown. The latter is the Crown's preference, but to date, claims relating to only 9 per cent of New Zealand's landmass have been directly negotiated with the Crown; the remaining 91 per cent have been involved in claims heard through Waitangi Tribunal hearings. In preparing for negotiations, claimants are required to give a mandate to representatives of their claimant group to advance their claim. This mandating process can create tensions and conflict within claimant communities (Jones 2016: 90) and has been a controversial aspect of the settlement process.

In the pre-negotiation stage - the second stage of the settlement processthe Crown and claimants agree to the terms of negotiations and establish which issues are on and off the table. Claimant funding is also determined. The Crown makes a contribution to claimant costs, which is separate from the redress received; claimants do not bear the cost of negotiations (OTS 2002: 54-60). 
The negotiations stage is led by OTS officials and claimant negotiators, but may also include officials from other government departments relevant to the negotiations. The negotiations are private and confidential to the parties involved. For the most part, negotiations escape media scrutiny and the public is unaware that negotiations are proceeding (unless a significant controversy arises) until they hear of the legislation reaching parliament. The objective of the negotiations phase is to reach an agreement in principle (also known as a heads of agreement) and then a deed of settlement (OTS 2002: 61-8).

Finally, ratification is a crucial step in the fourth stage of negotiations to test that the claimant community supports the outcomes. This is not simply a formality; there have been examples of claimant communities demonstrating their opposition to settlement packages, although only one claimant group, Whakatōhea, took the step, in 1996, of entirely rejecting the settlement at this point (Durie 1998: 198-9). To this day, Whakatōhea claims remain unsettled.

The implementation phase requires the claimant community to establish a post-settlement governance entity (PSGE) - a legal entity that can receive the settlement funds and assets. These entities have also been controversial for some Māori claimants. As Jones (2016: 99) notes, PSGEs are not entities based in Māori tikanga (culture), but rather are based on

models of corporate governance primarily concerned with financial propriety, commercial accountability, and economic sustainability ... Quite simply, PSGEs can be constituted in a way that leads decisionmakers to act in a way that is at odds with the principles of tikanga.

With negotiations completed and settlements ratified by claimant groups, nearly all deeds of settlement need to be implemented by settlement legislation. Settlement acts ensure the settlement is 'full and final' by removing the ability of the courts and the Waitangi Tribunal to reopen historical claims or deeds of settlement. The legislation also provides the statutory instruments required to implement the settlement, removes statutory memorials from land titles in the claim area and vests any land in the claimants' governance group. A settlement Bill ratifying negotiation follows the standard parliamentary process. The Bill is read three times and is subject to a select committee process that provides an opportunity for dissenting claimant groups to engage in further debate on the settlement package. The select committee stage is not, however, used to renegotiate the substance of the deed of settlement. As the OTS (2002: 78) explains, this 'reflects the long-established Parliamentary 
practice that Parliament should not use its sovereignty ... to change legal agreements between the Crown and a third party, unless this is necessary in the national interest'.

Since the first settlements in the 1990s, settlement acts have comprised a historical account and apology from the Crown, financial redress and cultural redress. In terms of restoring the relationship between claimants and the Crown, the historical account and Crown apology are arguably the most important aspect of the settlement. The historical account is a statement at the start of the legislation agreed to by the Crown and the claimants. It sets out the key facts of the historical relationship between the claimant group and the Crown and lays bare the treaty breaches the settlement addresses. The Crown then proceeds to express its regret and unreserved apology for those breaches and losses and for the resentment and grief suffered by Māori. These statements can be expressed in both English and in te reo Māori and may include karakia (prayers) and waiata (songs) significant to the claimants (OTS 2002: 85).

Crocker (2016: 173-4) notes that the Labour Government (1984-90) was not prepared to offer Māori an apology as part of a settlement, but the National Government took advice from officials during the WaikatoTainui negotiations to acknowledge the wrongs done and to apologise. The resulting Crown apology to Tainui in 1995 (delivered in person by the Queen during her royal visit) was 'ground-breaking' (Crocker 2016: 173). As Hickey (2012) argues, by the late 1990s, the government came to accept that reconciliation between Māori and the Crown required more than financial redress and restored cultural recognition. Minister Graham was responsible for the Crown's decision to formally acknowledge and apologise for the historical injustices the Crown had inflicted on Mãori. This would, in Graham's words, put those events in their 'proper placenot forgotten, but accepted' (Hickey 2012: 82). With few exceptions, apologies have become 'a valued part of the settlement process' (Hickey 2012: 90), which can 'help to recognise the validity of the grievances, reconcile the past and reset the Treaty relationship. It may also provide a sense of closure' (p. 91). Given the significance of the settlement apology, it is worth considering a Crown apology more closely as an example of an agreed account of New Zealand's colonial history now on the public record. The following is the Crown apology in the Ngäi Tuhoe (Claims) Settlements Act 2014 (Section 9): 
The Crown acknowledges that its conduct during its attacks on Te Urewera and its surrounds between 1865 and 1871 included-

(a) the failure to properly monitor and control the actions of the armed forces, resulting in-(i) the execution of unarmed Tühoe prisoners at Mangarua (near Waikaremoana) in 1866 and at Ngātapa in 1869; and (ii) the execution of Tūhoe prisoners at Ruatāhuna in 1869; and (iii) the killing of non-combatants, including men, women, and children, and the desecration of bodies, human remains, and urupā [burial grounds] at Te Whata-a-pona, Ōpūtao, Tahora, and in the Ruatāhuna district; and

(b) the use of the scorched earth policy that resulted in the widespread destruction of kāinga [settlements], pā [fortified settlements], cultivations, food stores, animals, wāhi tapu [sacred places], and taonga [treasures].

The Crown acknowledges that the impacts of these actions on Tühoe included widespread starvation and extensive loss of life. The Crown's actions had an enduring and devastating effect on the mana [authority/ prestige], social structure, and well-being of the iwi. The Crown acknowledges that its conduct showed reckless disregard for Tūhoe, went far beyond what was necessary or appropriate in the circumstances, and was in breach of the Treaty of Waitangi and its principles.

A second component of settlements is financial redress-the part of the settlement that is economic or commercial and given monetary value. The Crown has acknowledged that 'the losses to Māori amount to tens of billions of dollars' (OTS 2002: 89), but it has never offered complete compensation. Māori have compromised and settled for a fraction of the value of what was taken from them; the redress paid to Māori has been estimated at less than 1 per cent of the loss suffered (Stone 2012: 145). Financial redress includes cash and commercial redress in the form of Crown assets such as property (mostly held in land banks established in the 1990s). In determining financial redress, the Crown is guided by the principle that 'the quantum of redress should relate fundamentally to the nature and extent of the Crown's breaches of the Treaty and its principles' (OTS 2002: 87). The quantum offered is 'negotiated' by the Crown and claimants, although, as Stone (2012: 145) notes:

[S]ettling groups are faced with a difficult decision: they can either accept what most would consider a relatively minute settlement offer; take their chances in litigation against the Crown; or wait and see if Crown policy may change significantly in the future, resulting in more valuable settlements. 
While it is true the Crown has the upper hand in negotiations, Jones (2016: 91) notes that even the Crown is constrained by broader fiscal limits on the government's budget and the precedents set by earlier settlements. As noted above, the billion-dollar fiscal envelope was formally abandoned in 1996 and the billion-dollar cap was surpassed in 2012; however, the constraints of the relativity clauses are still in place.

The third component of a settlement package is cultural redress, encompassing, for example, the loss of Māori kaitiakitanga (guardianship) of significant sites, the loss of access to traditional mahinga kai (foodgathering places) and the exclusion of Māori from environmental decision-making (OTS 2002: 96). In considering cultural redress, the Crown makes it clear that it is required to balance the interests of Māori with the interests of the general public. Therefore, although the Crown usually does not return ownership of a resource to Māori, through cultural redress it can try to meet the underlying interests Māori have in that resource and establish a future relationship with the resource for Māori. Cultural redress aspects of the settlement package do not have a direct monetary value, so do not count against the financial redress negotiated between Māori and the Crown (OTS 2002: 98). A wide variety of cultural redress has been realised through treaty settlements since the very early Ngāi Tahu settlement included new ownership and management regimes for the taonga of pounamu (greenstone) and tìti (muttonbird) (Stevens 2012: 124).

Although the components described above are consistently applied to all settlements, two recent examples-the Ngai Tühoe settlement in 2014 and the Whanganui River settlement in 2017-demonstrate that the Crown will innovate beyond the established norms of treaty settlements and legislate new arrangements. Despite the Crown's policy that the conservation estate would not be available as settlement redress, the Ngai Tühoe settlement vested title to Te Urewera National Park in a new legal entity with representation from Ngai Tühoe and the Crown in equal measure. In this way, the Crown stopped short of actually transferring title of the national park to Tūhoe, while achieving an outcome that reflected the significance of the land for the claimants. In the case of the Whanganui River, the Te Awa Tupua (Whanganui River Claims Settlement) Act 2017 gives legal personality to the river itself and establishes a board (Te Pou Tupua) with Crown and iwi appointees as the human face of the river to promote and protect the river's health and wellbeing. Jones acknowledges the significance of these settlement innovations, but also notes their 
limitations, saying: 'These settlements make significant advances in terms of establishing a framework that reflects a Māori perspective on human relationships with the natural environment and specific landscape features', although they stop short of establishing a 'just' relationship between Māori and the government and of recognising Māori legal traditions (2016: 98).

The final phase of historical treaty settlements will bring additional challenges to the policy process. It is possible that not all Māori will settle with the Crown. The Post Settlement Commitments Unit, established in 2013 in the Ministry of Justice, will play an important role to ensure the durability of treaty settlements. The Waitangi Tribunal and the OTS will continue to evolve as their function and focus shift from historical to contemporary claims.

Beyond treaty settlements, there is other policy work to be done in relation to the treaty. After its election in 2017, the Labour-led Government signalled a new direction beyond settlements with the creation of a portfolio for Crown-Māori relations. This policy unit has also been located in the Department of Justice, and the newly appointed minister, Māori MP Kelvin Davis, is currently engaging with Māori through a series of hui (meetings) across New Zealand to consult on the roles and expectations of that policy in future.

\section{Conclusion}

Through the Treaty of Waitangi settlement process, New Zealand has made important, substantive progress in addressing its colonial past. By 2015, when the Waitangi Tribunal celebrated its fortieth anniversary, it had registered about 2,500 claims, partly or fully reported on over 1,000 claims, published more than 100 final reports and issued district reports covering almost 80 per cent of New Zealand's landmass (Waitangi Tribunal 2015). The tribunal's work has laid the basis for most settlements negotiated between Māori and the Crown that acknowledge the Crown's breaches of the Treaty of Waitangi. The Crown has apologised unreservedly to Māori for treaty breaches and taken steps to establish new relationships with Māori. Māori have finally had their grievances acknowledged on the public record, have heard the Crown atone for its past actions, have been provided an economic base on which to build and, in many cases, have had important cultural connections with land and resources formally restored. As Cowie (2012: 64) notes: 
[T]he settlement process is not just about spending money and reaching settlements. Loftier nation-building outcomes are being realised. The process restores the honour, or moral legitimacy, of the Crown to govern on behalf of all New Zealanders. It also affords to Mãori the opportunity to take real ownership of a future that is different from their past. These intangible benefits of reaching settlements-international respect, a truly post-colonial government, tribes with economic power and sound governance that instil pride and confidence in their people-could yet prove to be the most significant legacies of the Treaty settlement process.

Despite its controversial place in New Zealand society, the ambitious programme of negotiating historical claims comprehensively, finally and quickly has seen significant success. (p. 62)

As noted in this chapter, the policy has gained cross-party support. 'It appears that everyone, including most Màori and politicians, want the job completed, fast' (Cowie 2012: 62). And, as the OTS noted in its briefing to the incoming minister in 2017:

While not all elements of the Treaty settlement process are universally supported, settlements have been signed with $61 \%$ of all expected groups and have traditionally enjoyed broad cross-party support. Treaty settlements have also gained greater public understanding and support over the last two decades. (OTS 2017: 3)

The treaty settlement process has also endured through time as both Māori and the Crown have evolved in response to changing circumstances. Despite the Crown's extensive control over the treaty settlement policy, it has been moulded and shaped by the settlement process over the years (Dreaver 2017: 114). In the 1990s, the government backtracked on its ambition to negotiate pan-Māori settlements and also formally abandoned the fiscal envelope in the face of fierce Māori opposition. More recently, it has found innovative ways to navigate around the principles that national parks will not be transferred to Māori through settlements (Dreaver 2017: 120). Iwi have also 'changed considerably, and ... have an increased capacity now to take responsibility for their own destinies' (Dreaver 2017: 128). Moreover, iwi leaders now have a profile in public discourse that did not exist when the first settlements were made over 20 years ago. Pan-Māori organisations and leaders who dominated the political landscape prior to settlements—as Māori demanded the Crown's attention-have diminished in profile. Settlements have also created new levels of resilience and capacity among iwi. As Dreaver (2017: 124) notes, 
the negotiating process has provided mandated iwi groups and negotiators 'with resources to establish and maintain a level of operational capability, which, in a modern setting, had never existed'.

The public has also been changed by settlements policy. '[F]or the public, the settlements process has arguably been highly transformative, in a way that has at times been subtle and slow, but seems also constant and immutable' (Dreaver 2017: 126). As Durie notes, after the tribunal's establishment in 1975 :

[it] began to sketch an historical backdrop which had been largely hidden from the eyes of ordinary New Zealanders. Case by case there was examination of injustices that had never been resolved in the past, nor openly admitted, and again and again it was found that the Crown had failed to meet its obligations under the Treaty. Most New Zealanders were surprised to know that the Crown did have Treaty obligations. (Durie 1998: 175)

Generally, public concern has diminished over time; where treaty settlements used to be in the top five concerns of voters at election time, now they rarely feature (Dreaver 2017: 125).

McConnell (2010: 351) defines a policy as successful if 'it achieves the goals that proponents set out to achieve and attracts no criticisms of any significance and/or support is virtually universal'. By this definition, the treaty settlements policy is a success, but the numerous criticisms of the policy are important to consider and tend to focus on its limited objectives with regard to outcomes for Mãori. Dreaver (2017: 116) notes that settlements 'are not about restoring the status quo of Māori groups as they existed in 1840'. And Sharp (1997: 285) argues: 'Justice for the Māori ... can never be done. It will never be done.' But, he acknowledges, 'there is enough political community' between Māori and the Crown 'for justice to be negotiated' (Sharp 1997: 285, 287). There are differences in the benefits that have accrued to iwi who settled early compared with those who have had to wait significantly longer to settle (Dreaver 2017: 124-5). Some Māori are still waiting, and a small proportion may never settle. As Sharp (1997: 299) warned when the process was in its infancy in the 1990s:

[S]ettlements will be seen to have borne little relationship to questions of need or any other conceptions of distributive justice. Reparation has been made and will be made to the best organised teams, not to the most needy. 
Finally, as Jones (2016: 107) concludes, settlements are 'symbolic reparation' that acknowledge the grievances suffered by Māori across New Zealand, restore relationships between Māori and the Crown for the future (Dreaver 2017: 120) and restore the Crown's honour.

So what policy lessons can be learned by other nations from New Zealand's treaty settlements? Sharp (1997: 283) argues that, in relation to other nations dealing with reparations for Indigenous peoples:

precisely what should be repaired and how is arbitrary and unpredictable by the use of reason. It is a matter rather of long history, of the conventions of particular societies constructed only semi-consciously over long tracts of time ... The metaphors of reparation, remedy and restitution, and so on ... [vary] from society to society.

Treaty settlement policy has succeeded to the extent that it has for a number of important reasons that may be unique to the New Zealand experience. But those circumstances are worth consideration all the same. Māori have maintained pressure on the government to honour the treaty since it was signed in 1840. From the 1970s, when their voice could no longer be ignored, National and Labour governments alike demonstrated a commitment to addressing and redressing treaty grievances; that commitment has been maintained through time despite strong ongoing public ambivalence about the policy. Settlements have been a political process, not a legal one, and governments have set limits and expectations on what treaty settlements can and will achieve as symbolic reparative justice.

\section{References}

Anderson, A., Binney, J. and Harris, A. 2014. Tangata Whenua: An illustrated history. Wellington: Bridget Williams Books.

Boast, R. 2005. Foreshore and Seabed. Wellington: LexisNexis.

Cowie, D. 2012. 'The treaty settlement process.' In N. Wheen and J. Hayward (eds), Treaty of Waitangi Settlements. Wellington: Bridget Williams Books. doi.org/10.7810/9781927131381_3.

Crocker, T. 2016. Settling treaty claims: The formation of policy on Treaty of Waitangi claims in the pioneering years, 1988-1998. PhD thesis, Victoria University of Wellington, Wellington. 


\section{SUCCESSFUL PUBLIC POLICY}

Department of Justice 1989. Principles of Crown Action on the Treaty of Waitangi. Wellington: Government of New Zealand.

Dreaver, M. 2017. 'Coming of age: Transformation and the treaty settlement process.' In R. Bell, M. Kawharu, K. Taylor, M. Belgrave and P. Meihana (eds), The Treaty on the Ground: Where we are headed and why it matters. Auckland: Massey University Press.

Durie, M. 1998. Te Mana Te Kawanatanga: The politics of self-determination. Auckland: Oxford University Press.

Graham, D. 1997. Trick or Treaty. Wellington: Institute of Policy Studies.

Hamer, P. 2004. 'A quarter century of the Waitangi Tribunal.' In J. Hayward and N. Wheen (eds), The Waitangi Tribunal: He roopu whakamana i Te Tiritio Waitangi. Wellington: Bridget Williams Books. doi.org/10.7810/9781877242328_1.

Hickey, M. 2012. 'Apologies in treaty settlements.' In N. Wheen and J. Hayward (eds), Treaty of Waitangi Settlements. Wellington: Bridget Williams Books. doi.org/10.7810/9781927131381_5.

Jones, C. 2016. New Treaty, New Tradition: Reconciling New Zealand and Māori law. Wellington: Victoria University Press.

McConnell, A. 2010. 'Policy success, policy failure and grey areas in-between.' Journal of Public Policy 30(3): 345-62. doi.org/10.1017/S0143814X 10000152.

Marsh, A. and McConnell, A. 2010. 'Towards a framework for establishing policy success.' Public Administration 88(2): 564-83. doi.org/10.1111/j.1467-9299. 2009.01803.x.

New Zealand. Royal Commission on Social Policy 1988. The April Report. Vols 1-5. Wellington: Government of New Zealand.

Office of Treaty Settlements (OTS) 1994. Crown Proposals for the Settlement of Treaty of Waitangi Claims. Wellington: Department of Justice.

Office of Treaty Settlements (OTS) 2002. Ka Tika à Muri, Ka Tika a Mua: Healing the past, building a future-A guide to Treaty of Waitangi claims and negotiations with the Crown. Wellington: Department of Justice.

Office of Treaty Settlements (OTS) 2017. Vote treaty negotiations. Briefing for the incoming minister. Wellington: Department of Justice.

Orange, C. 1987. The Treaty of Waitangi. Wellington: Allen \& Unwin and Port Nicholson Press. 
Palmer, M. 2008. The Treaty of Waitangi in New Zealand's Law and Constitution. Wellington: Victoria University Press.

Sharp, A. 1997. Justice and the Mãori: The philosophy and practice of Māori claims in New Zealand since the 1970s. 2nd edn. Auckland: Oxford University Press.

Stevens, M. 2012. 'Settlements and taonga: A Ngāi Tahu commentary.' In N. Wheen and J. Hayward (eds), Treaty of Waitangi Settlements. Wellington: Bridget Williams Books. doi.org/10.7810/9781927131381_9.

Stone, D. 2012. 'Financial and commercial dimensions of settlements.' In N. Wheen and J. Hayward (eds), Treaty of Waitangi Settlements. Wellington: Bridget Williams Books. doi.org/10.7810/9781927131381_10.

Waitangi Tribunal 1997. Te Manutukutuku, No. 41. Wellington: Waitangi Tribunal.

Waitangi Tribunal 2015. Te Manutukutuku. No. 68. Wellington: Waitangi Tribunal.

Walker, R. 2004. Ka Whawhai Tonu Matou: Struggle without end. Auckland: Penguin.

Ward, A. 1999. An Unsettled History: Treaty claims in New Zealand today. Wellington: Bridget Williams Books.

Wheen, N. and Hayward, N. (eds) 2012. Treaty of Waitangi Settlements. Wellington: Bridget Williams Books. 
This text is taken from Successful Public Policy: Lessons from Australia and New Zealand, edited by Joannah Luetjens, Michael Mintrom and Paul 't Hart, published 2019 by ANU Press, The Australian National University, Canberra, Australia.

doi.org/10.22459/SPP.2019.17 